\title{
NOTAS
}

\section{Manuel Gálvez (1882-1963)}

I A desaparición de Manuel Gálvez, fallecido este año en Buenos Aires, 1 representa el fin de una época en la literatura argentina: la del realismo finisecular, cuya iniciación con La Gran Aldea de Lucio V. López señala un nuevo ámbito y una nueva atmósfera en nuestras letras. Fue la etapa del positivismo en ideas, del crecimiento económico supeditado a influencias extranjeras, de la cultura extremadamente europeizada pero, a un mismo tiempo, en algunos y, entre ellos, Manuel Gálvez, de la adquisición de una conciencia nacional. Nombres como los de Eugenio Cambaceres (cuya obra espera todavía un examen atento), Julián Martel, Roberto J. Payró y Benito Lynch jalonan su historia con dignidad y con interés. La novela argentina de ese entonces se coloca a la vanguardia de la novelística latinoamericana y precede al gran movimiento nativista e indigenista posterior a 1920.

Manuel Gálvez, el más prolífico de los novelistas de este grupo nació en Paraná, provincia de Entre Ríos, en 1882 (I8/VII); fueron sus padres don Manuel Gálvez y doña Angela Balugera, ambos de muy viejas taíces criollas que llegan hasta los tiempos de la colonización del Río de la Plata y vinculados a Juan de Garay y a Hernandarias. Entre sus antepasados figutan un colector de la Santa Cruzada y un familiar del Santo Oficio; un tío suyo, el doctor José Gálvez, fue prohombre de la provincia y de la ciudad de Santa Fè y contribuyó a la creación de su puerto y de su universidad, intervino en los proyectos de ferrocarriles y colonias y fundó un diario, La Nueva Epoca, en cuyas páginas su sobrino Manuel, estudiante entonces del bachillerato, publicó sus primeros artículos y bocetos. Gálvez pasa su infancia, sus años de pubertad y su 
adolescencia en Santa Fé, adonde se había trasladado su familia en I885, e hizo sus estudios secundarios en el Colegio de la Inmaculada de esa ciudad. En r889, sus padres lo enviaron a Buenos Aires a estudiar Derecho, destino común en la época de todos aquellos jóvenes cuya vocación fuera las humanidades; la Facultad de Filosofía y Letras de la capital reabría sus puertas justamente ese año, después de un primer intento fracasado en 1884 ; Gálvez asistió a sus aulas, pero no se inscribió como alumno.

En 1904, flamante abogado y modesto funcionario judicial, era ya conocido en el mundillo literario porteño, en el que había tomado la iniciativa de editar, con otros amigos, una nueva revista, Ideas. La nueva generación, la del posmodernismo, necesitaba un medio de expresión, que halló en Ideas y por la voluntad y tesón de sus dos directores: Gálvez y Ricardo Olivera. La revista duró, con las naturales intermitencias, tres años, de 1903 a I906, y llena el espacio entre las finiseculares revistas modernistas, la académica $L a$ Biblioteca de Groussac y la aparición de Nosotros en 1908. Colaboraron en ella jóvenes cuyo prestigio y mérito se confirmó y afianzó con los años, como Ricardo Rojas, Emilio Becher, Alberto Gerchunoff, Juan Pablo Echagüe, Horacio Quiroga y otros, posteriormente atraídos por distintos intereses, como Abel Cháneton, Mario Sáenz y Salvador Oría. He aquí cómo la define y la recuerda el mismo Gálvez:

...no obstante que admirábamos y queríamos a Rubén Darío y admirábamos a algunos de sus corifeos, los juzgábamos con libertad de espíritu. Careciamos de fervor hacia las princesas, las marquesas versallescas y la Grecia de tercera mano que nos evocaban el maestro y sus discípulos inmediatos. Nosotros éramos mucho menos cosmopolitas que ellos, y en nuestra subconsciencia se agitaban ya, seguramente, las imágenes de los seres y las cosas de nuestra tierra, que hariamos vivir más tarde en nuestros libros. Nosotros asesinamos a los faunos y a las marquesas de empolvadas cabelleras.

Su credo, con muchísimas variantes, el socialismo o el anarquismo; el tolstoísmo, Wagner en música y el realismo naturalista que el gran director Antoine iba imponiendo lentamente, en el teatro, para desterrar la sensiblería y el convencionalismo de los autores fáciles del boulevard. Si algunos eran "materialistas", los más buscaban un nuevo espiritualismo de acuerdo con un sentimiento contemporáneo. De todos mo- 
dos, estos años fueron de crisis ideológica para Gálvez; educado en un hogar católico, con los jesuitas, conmovido en sus costumbres y en sus creencias en la Universidad, él mismo indica que, de los veinte a los veinticinco años, perdió la seguridad que dan las convicciones bien arraigadas; en 1907 encuentra la tranquilidad perdida y, desde entonces, Gálvez representa en las letras argentinas el realismo como escuela, el liberalismo, pese a sus simpatías por el rosismo, en ideas sociales, no en las económicas, y el nacionalismo en la interpretación de los problemas argentinos. Tal vez pueda parecer contradictorio este juicio en el que se presenta como liberal al autor de la Vida de Don Juan Manuel de Rosas (I94I) y de la Vida de Don Gabriel Garía Moreno (1942), tan opuestas a la Vida de Hipólito Yrigoyen (1939); entiendo como liberal, en este caso, no al apologista de una dictadura, sino a quien ha tratado de mostrar en algunas figuras históricas, verdad es que enérgicas y dictatoriales, si se quiere fanáticas, a los intérpretes de una voluntad de masa, de pueblo, desconocida o negada por círculos intelectuales imbuidos de doctrinas de un liberalismo foráneo y antitradicional en sus países. Este es un matiz que es indispensable recordar y subrayar cuando se juzga nuestra historia latinoamericana y a sus escritores. Desde 1936 , Gálvez queda clasificado, señala su biógrafo Anzoátegui, como antidemocrático (Manuel Gálvez, Buenos Aires, 196r). Su última novela, Tránsito Guzmân, nos da una clave para estimar adecuadamente su pensamiento en esto.

Su vida y su formación literaria las examina Gálvez en un libro indispensable para todo aquel que quiera entender el espíritu de su generación: Amigos y maestros de mi juventud (1944); sus opiniones coin. ciden con anticipos que pueden irse rastreando en ensayos anteriores ( $E l$ diario de Gabriel Quiroga, I910; La vida múltiple, 1916; El espiritu de aristocracia y otros ensayos, 1924). De otro carácter, libro de viajes pero, sobre todo, de reencuentro, El solar de la raza (I9r3), es, a mi juicio, uno de los más bellos, y de los pocos bien escritos, de un autor despreocupado por la corrección y por la belleza formal.

Una primera etapa en su producción se cierra con La pampa y sa pasión (I926). Gálvez cuenta en su haber de novelista con ocho novelas y, entre ellas, las de mayor fama: La maestra normal (1914), El mal metafisico (r9r6), y Nacha Regules (r9r9). Carmelo M. Bonet dice de la primera: "justificado éxito", de la segunda: "la novela más humanizada... Retratos y más retratos. Alguna vez supera el retrato... 
(Carlos Riga)", y de la última: “. . Novela sombría, está denunciando lecturas frescas del maestro de Medán" (Historia de la Literatura Argentina, IV, Buenos Aires, Peuser, 1959). Raselda Gómez, la maestra normal, me parece una figura lo suficientemente bien trazada como para merecer un juicio menos impersonal que el de Bonet. No puede caber ninguna duda sobre la conducta artística de su creador: a Gálvez no le interesa el estilo, rechaza por temperamento todo adorno y artificio; tealista convicto y confeso, sus valores hay que buscarlos en la creación de personajes; tampoco se preocupa mucho por sus argumentos, por lo general flojos y trillados. Realismo liso y copia directa de la vida que lo rodea. Si nos colocamos en esta actitud, Raselda Gómez, la maestra provinciana; Carlos Riga, el joven poeta "enfermo del mal metafísico" y vagabundo en la metrópoli; Nacha Regules, la prostituida, cobran vigor y adquieren su fuerza de testimonios humanos; no de héroes o de símbolos, que no es lo que va buscando Gálvez, sino de trasuntos de esa humanidad común, en cuyo roce cotidiano el novelista persigue sus temas y sus personajes en esta época de su producción. Puede discutirse si este realismo a ras de tierra merece o no honores en la valoración estética; pero no puede negarse que Gálvez cumple con las exigencias de la escuela en que se coloca.

Posteriormente, y a partir de Los Caminos de la muerte, inicia una segunda época en la cual su interés se dirige básicamente a la novela histórica y a las biografías, abandonando así su preocupación por la realidad más inmediata contemporánea. No cabe duda de que, hasta cierto punto, una postura deriva de la otra y de que prolonga, en esta forma, la interpretación del problema presente en la búsqueda de su arraigue tradicional. Es entonces cuando retorna al primer fundamento de su educación; al catolicismo de su hogar y de sus estudios preuniversitarios, a un sentimiento nacional y criollo. Tránsito Guzmán es la obra en la que vuelve a ocuparse de lo contemporáneo. Toda esta segunda etapa se caracteriza por una labor de creación menos vigorosa y de tipos humanos menos destacados, como lógica consecuencia de la nueva postura del autor.

Gálvez es, en su totalidad, un escritor destacado en el ambiente intelectual argentino; de larga vida y abundante obra; en su primera etapa fue una honesta y popular figura del realismo; en la segunda, un convencido intérprete de lo que se ha llamado en la Argentina el revisionismo histórico, o sea, tradición de fuerte inspiración nacional y criollista. Su 
producción muestra notables altibajos, sus actitudes sociales y políticas lo hacen sujeto de controversia, pero creo que algunas de sus mejores novelas ya pertenecen al acervo nacional por su valor de documento realista y logrado de la sociedad en la que vivió y trabajó.

University of Cbicago

BernaRdo BLANCO-GONZÁLEZ 
